\title{
COVID-19: МУЛЬТИДИСЦИПЛІНАРНІ ДОСЛІДЖЕННЯ ЩОДО ВИВЧЕННЯ ДІЯЛЬНОСТІ ЩИТОПОДІБНОЇ ЗАЛОЗИ ПІД ЧАС ПАНДЕМІЇ ТА ПОСТКОВІДНИХ ПРОЦЕСІВ
}

\section{COVID-19: MULTIDISCIPLINARY STUDIES ON THE THYROID ACTIVITY DURING THE PANDEMIC AND POST-COVID PROCESSES}

Ольга Рябуха (Olha Ryabukha), кандидат медичних наук, доцент, ТзОВ «Львівський медичний інститут», Львів, Україна

\begin{abstract}
In the current global spread of the COVID-19 pandemic, which is observed among all segments of the population, the thyroid gland can play a leading role in both the clinical course of the disease and in the processes of post-covidal recovery of human functional activity. It is multidisciplinary research that covers such areas as medicine, mathematics, pharmacy, law, etc., confirms the importance of the thyroid gland to ensure vital functions. In this case, the disclosure of the deep essence of the processes occurring in it in the norm and pathology is possible on the basis of innovative use of correlation analysis with the designing of correlation portraits of the main follicular thyrocytes' activities.

Keywords: multidisciplinary research, COVID-19, postcovid processes, restoration of functional activity, thyroid gland, hypothyroidism, follicular thyrocytes, mathematical methods in medicine, correlation analysis, correlation portrait.
\end{abstract}

Вступ. Станом на 25.01.2022 p. кількість хворих на Covid-19 в 224 країнах світу становила 357526297 [1]. Із них 283399075 хворих одужали, летальні випадки зафіксовано в 5627584 пацієнтів. Від початку пандемії найбільше захворілих на Covid-19 зареєстровано у США (72 958 690), Індії (39 799 202), Бразилії (24 134 946), Франції (17 302 548), Великий Британії (16 047 716); у світовій статистиці Україна посідає 18-те місце за загальною кількістю випадків Covid-19 (3 889 488). За даними МОЗ України [2] станом на 25 січня 2022 року в Україні встановлено 19118 нових підтверджених випадків коронавірусної хвороби Covid-19 (з них дітей - 2 809, медпрацівників - 594).

Поширенню пандемії Covid-19 та ускладненням захворювання може сприяти наявність у хворих ендокринних порушень. У цьому аспекті увагу акцентують переважно на цукровому діабеті. Водночас патологія щитоподібної залози (ЩЗ), яка за поширеністю посідає друге місце після цукрового діабету [3], спостерігається у понад 200 млн людей усього світу [4]. Зазначимо, що ЩЗ - це ендокринний орган, який виробляє тироксин (Т4), трийодтиронін (Т3) та тиреокальцитонін, які $€$ есенціально необхідними для нормального 
функціонування практично всіх органів та систем організму [5]. В Україні кількісний показник захворюваності на різні нозології ЩЗ за останні 5 років збільшився в п’ять разів [6]; показник залежить від ряду факторів: екологічних особливостей зовнішнього середовища, йодного забезпечення організму, повноцінності харчування, способу життя, наявності стресових чинників, наявності супутніх захворювань та їх нозологічних форм тощо.

Дані доклінічних та клінічних досліджень дають підстави вважати, що Щ3 може бути органом-мішенню для SARS-CoV-2 [7,8]. За умов пандемії Covid-19 пацієнти, в яких не контролюють рівень гормонів ЩЗ в крові, можуть наражатися на тяжчий перебіг хвороби та підвищений ризик постковідних ускладнень. Своєю чергою, високі дози стероїдних препаратів, які застосовують при Covid-19 як протизапальний засіб, мають здатність пригнічувати імунну систему, що підвищує ризик тяжкого перебігу захворювання. Беручи до уваги, що діяльність ЩЗ і надниркових залоз регулюється системою "гіпоталамус - гіпофіз" та наявністю осі "щитоподібна залоза - надниркові залози", зазначене актуалізує залучення до проблем дослідження Щ3 широкого кола спеціалістів [9]. В умовах пандемії Covid-19 мультидисциплінарні дослідження спеціалістів клініко-фармакологічних, класифікаційно-правових та номенклатурно-правових груп у сфері охорони здоров'я повинні сприяти об'єднанню міждисциплінарних зв'язків у галузі медицини, фармації, права, економіки для досягнення високої якості медичних послуг для всіх контингентів пацієнтів [10-12].

Основним напрямком діяльності організму є постійна саморегуляція, завдяки якій відбувається узгоджена діяльність органів і систем, що $\epsilon$ необхідною умовою адекватного реагування на постійні зміни в середовищі. Функції контролю за перебігом процесів, що відбуваються в організмі, та їх координацію здійснюють нервова, імунна та ендокринна системи, при цьому важливою складовою частиною ендокринної системи є ЩЗ, яка відіграє важливу роль у всіх видах обміну, процесах росту та диференціації тканин, термогенезі; однією з провідних функцій ЩЗ є регуляція міжклітинного 
енергообміну, що необхідне для засвоєння ними кисню $[13,14]$. На значення Щ3 для діяльності організму вказує підвищена чутливість до тиреоїдних гормонів тканин печінки, серця, нирок, скелетних м'язів, синовіальних фібробластів; мозок теж має рецептори до тиреоїдних гормонів, що робить його мішенню для Т3. Проте нині патологія ЩЗ, посівши одне із провідних місць серед усієї сукупності ендокринних розладів, характеризується виразною тенденцією до зростання [15]. Захворювання ЩЗ мають причинно-наслідкові зв'язки 3 підвищеним ризиком розвитку інших розладів здоров'я [16], включно з серцевосудинними захворюваннями, цукровим діабетом [17], метаболічним синдромом, ожирінням, захворюваннями нирок, депресією, тривожними розладами [18]. Останніми роками моніторинг за станом тиреоїдної патології засвідчив, що абсолютний приріст вперше виявлених захворювань в економічно розвинених країнах становив 52\% серед жінок і $17 \%$ серед чоловіків, при цьому збільшилася кількість хворих із доброякісними вузловими утвореннями та злоякісними пухлинами.

Найпоширенішим розладом діяльності ЩЗ є гіпотиреоз, зумовлений аліментарним дефіцитом йоду. Захворювання призводить до численних дисфункцій переважної більшості органів і систем, що стає причиною порушень в узгодженій роботі організму [19]. Попри те, що вивчення цього виду гіпотиреозу триває ще 3 19-го ст., у діагностиці та лікуванні йододефіцитних станів залишається багато питань, які не мають однозначного трактування. За даними різних досліджень останніх років, до 40\% населення світу (близько 2,8 мільярдів осіб) мають ризик виникнення і розвитку патології ЩЗ, пов’язаної з дефіцитом йоду як субстрату для продукування тиреоїдних гормонів: у 2010 р. це спричинило втрату 4 мільйонів життів пацієнтів 3 інвалідністю [4].

Особливої гостро потреба в поглибленому дослідженні ЩЗ постала в умовах пандемії коронавірусної інфекції SARS-CoV-2 [20]. Учені-медики уважно стежать за "Delta"-варіантом Covid [21], який спричинив велику кількість захворювань у Великій Британії та інших країнах світу, та наслідками 
дії нового штаму Covid-19 "Omicron". Основні симптоми штаму Omicron мають певну подібність до банальної респіраторної вірусної інфекції [22]: у 73\% випадків спостерігається нежить, у 67,5\% - головний біль, у 63,5\% - втома, у $60 \%$ - чхання та біль у горлі. Вченими виявлено, що штам Omicron відтворюється в бронхіальній тканині у 70 разів швидше, ніж штам Delta $[23,24]$. Вважають, що зростання кількості штамів SARS-CoV-2 потенційно "допомагає" вірусу ефективніше пристосуватися та мімікрувати.

Попри те, що основною мішенню коронавірусу SARS-CoV-2 є дихальна система, рецептори до ангіотензинперетворювального ферменту 2-го типу (АПФ2), через які він потрапляє в клітини, виявлено також і в структурах ЩЗ [25]. Зазначене вказує на високу ймовірність ураження залози за умов коронавірусної пандемії, тому цілком слушною є думка Khoo B., Tan T., Clarke S.A. et al. (2021) щодо необхідності вивчення функції ЩЗ в нормі, під час Covid-19 та після закінчення хвороби [26]. Таким чином окреслена проблема $є$ комплексною і потребує залучення фахівців багатьох напрямків.

Беручи до уваги дослідження Чоп'як В.В. та Федорова Ю.В. (2005), Регеди М.С. (2015), Гайдучка І.Г. та Шаповалова В.В. (2022), Шаповалової В.О. (2021), Рябухи O.I. (2017, 2018, 2019, 2020, 2021), Рябухи O.I. та Федоренко B.I. (2021) [27-39], постає питання про необхідність створення міжвузівської мультидисциплінарної робочої групи з розробки та вдосконалення медичних стандартів у вигляді уніфікованих клінічних протоколів щодо медичної допомоги хворим на Covid-19, розроблених на засадах доказової медицини i доказової фармації у відповідності до МКХ-11 [40,41]. У такому разі можливість виходу за межі якоїсь однієї галузі медицини, фармації, економіки та права передбачає комплексне застосування фізіологічних, морфологічних [42-44], гістохімічних [45,46], біохімічних $[47,48]$, клінічних, фармацевтичних, фармако-економічних, технологічних, юридичних й інших [49] напрямків наукових досліджень та вивчення судово-фармацевтичних ризиків.

Метою нашої роботи $є$ дослідження та характеристика тиреоїдної патології в контексті перспективи проведення мультидисциплінарних 
досліджень щодо основних напрямків діяльності фолікулярних тироцитів за умов норми та патології.

Матеріали та методи дослідження. Дослідження проведене 3 використанням бібліографічних баз даних Google Sholar та Scopus на підставі ключових слів: коронавірусна інфекція SARS-CoV-2, щитоподібна залоза, фолікулярний тироцит, органічний йод, неорганічний йод, математичні методи в медицині, контент-аналіз, кореляційний аналіз, кореляційний портрет. Робота виконана у межах навчально-дослідницької теми ТзОВ «Львівський медичний інститут» "Удосконалення системи обігу ліків під час фармакотерапії на засадах доказової і судової фармації, організації, технології, біофармації та фармацевтичного права" (№ державної реєстрації 0120U105348, термін виконання 2021-2026).

Результати дослідження та їх обговорення. Уявлення щодо причин та механізмів розвитку тиреоїдної патології в міру накопичення відповідних наукових знань зазнають змін: етіопатогенез деяких захворювань ЩЗ уточнено, доповнено або й переглянуто. Насамперед це стосується ії мутаційних та генетичних уражень. Вважають, що саме мутації часто $є$ поштовхом до виникнення гіпотиреозів, зумовлених порушенням надходження йоду в ЩЗ внаслідок розладів механізмів його проходження через мембрану тироциту, порушення органіфікації за участю тиреоїдної пероксидази, розладів синтезу чи секреції тиреоїдних гормонів. Дисгормоногенез переважно зумовлений генетично - у дівчаток він трапляється у 2-3 рази частіше, ніж у хлопчиків. Також установлено, що тиреоїдна патологія є частим супутником розладів імунітету: основою певної частини тиреоїдитів, порушень функціональної активності залози та гіперпластичних розростань у ній $є$ автоімунні процеси, які призводять до деструкції фолікулів та заміщення їх на сполучну тканину 3 подальшим фіброзуванням. Припускають, що однією 3 причин зростання частоти автоімунних захворювань ЩЗ може бути існування феномену молекулярної мімікрії у деяких бактерій та вірусів, зокрема таких, як віруси Коксакі, паротиту, адено- та цитомегаловірус. Зростає і частота пухлинних 
утворень Щ3 [50]. Збільшення частоти радіаційно-індукованих форм раку ЩЗ [51], виникнення яких раніше вважали локальною патологією післявоєнної Японії або післячорнобильської України чи Білорусії, набуло особливої актуальності після аварії на атомній станції Фукусіма-1, яка призвела до радіаційного забруднення вод океану. У цьому аспекті необхідно зазначити, що час розвитку радіаційно-зумовленої тиреоїдної патології становить 30 і більше років, що потребує тривалого або й постійного моніторингу за станом ЩЗ [52].

Вже давно було помічено, що для етіопатогенезу гіпотиреозу, який перебігає у формі ендемічного вола, велике значення мають умови життя населення, його соціальний і культурний рівень. Антисанітарія, потрапляння в питну воду стічних вод, одноманітне харчування з переважанням у раціоні вуглеводів при одночасному дефіциті тваринних білків, ретинолу та вітамінів групи В (насамперед, тіаміну та ціанкобаламіну), дисбаланс мікро- та макроелементів (селену, заліза, кальцію) можуть стати підгрунтям виникнення ендемічного вола. Певну роль може відігравати надмірне споживання таких харчових рослин-гойтрогенів як капуста, бруква, соя, редис, які превалюють у харчовому раціоні соціально незахищених прошарків населення [53]. Усе більше увага вчених спрямована на проблему тиреодизрапторів - різноманітних екзогенних хімічних речовин переважно антропогенного походження, які здатні індукувати тиреоїдну дисфункцію [54,55]. Такими речовинами $є$ широке коло засобів побутової, промислової та сільськогосподарської хімії [56,57].

Проте переважну частку тиреоїдної патології становлять стани, зумовлені дефіцитом йоду в довкіллі. Для їх позначення використовують термін "йододефіцитні захворювання" [58]. Хоча для всіх них характерне зниження функціональної активності Щ3, спектр клінічних проявів йододефіцитних захворювань та їхні наслідки для організму залежать від багатьох факторів: віку, з якому організм зазнає дефіциту йоду, ступеня йодної недостатності, мікро- та макроелементного стану ареалу проживання. Дефіцит йоду в дорослому віці супроводжується гіперплазією ЩЗ та розвитком клінічних проявів гіпотиреозу. У дитячому і підлітковому віці він призводить до 
порушення фізичного, розумового і статевого розвитку. Якщо дефіцит йоду відчувається вже на етапі ембріонального розвитку, зростає частота самовільних викиднів, вроджених вад розвитку, вродженого гіпотиреозу; згодом у таких дітей спостерігається відставання у фізичному і розумовому розвитку. Украй тяжким проявом вродженого дефіциту йоду $є$ ендемічний кретинізм, для якого характерні низький рівень інтелекту, дизартрія, порушення ходи, спастична ригідність кінцівок, мікседема, гіперпластичне розростання тканини ЩЗ. Таким чином, основним наслідком дефіциту йоду не є локальне ураження Щ3 - у патологічний процес залучаються всі системи організму.

Профілактику йододефіцитних захворювань проводять додатковим введенням йоду в харчові продукти (йодуванням солі, хліба, чаю, печива, молока, соусів тощо), вживанням його таблетованих препаратів або застосуванням внутрішньом'язових ін'єкції йодованих олійних препаратів. Нині йодування здійснюють неорганічними йодовмісними сполуками переважно калію йодатом, який є стійкішим до зберігання та зовнішніх впливів, ніж калію йодид, який використовували раніше [59-61]. Як альтернатива неорганічному йоду вже тривалий час вивчається можливість використання його органічних сполук [62]. Особливо перспективним вважається використання морських водоростей - доведено, що вони активізують обмінні процеси, інтенсифікують синтетичну активність тироцитів, поліпшують загальний стан організму [63]. Однією з лікарських рослин, що застосовується у традиційній та народній медицині для лікування та профілактики гіпотиреозу, легких форм базедової хвороби, ендемічного зобу, є ламінарія (Laminaria), терапевтична дія якої зумовлена високим вмістом йоду [64]. Високу здатність посилювати синтетичну активність ЩЗ за умов аліментарного дефіциту йоду має йодобілковий препарат із чорноморської червоної водорості філофори ребристої (Phyllophora nervosa) [65].

Найповніше оцінити ступінь ураження Щ3, провести диференційну діагностику, розробити ефективну науково обгрунтовану фармакотерапію чи 
корекцію тиропатій можна на підставі даних морфо-функціональних досліджень органу [66]. Щ3 як цілісна біологічна структура одночасно функціонує на трьох рівнях інтегрування в ієрархічну систему організму: органело-клітинному, тканино-органному, системно-соматичному $[67,68]$. Беручи до уваги, що базисним рівнем організації будь-якої тканини є її клітина, а коректний аналіз та інтерпретація результатів морфологічних досліджень клітин можливий тільки з урахуванням їхньої функції, нами запропоновано інноваційний підхід до дослідження діяльності ЩЗ, оснований на характеристиці морфо-функціональних особливостей фолікулярних тироцитів при різноманітних впливах [69]. У такому разі діяльність гормонопоетичної клітини можна представити як таку, що відбувається чотирма напрямами: 1) синтез гормону, 2) секреція гормону, 3) транспортування гормону інтраорганним мікрокапілярним руслом, 4) енергетичне забезпечення цих процесів. Кожен із зазначених напрямів діяльності ми позначаємо як "можливість", реалізація якої відбувається спеціалізованими органелами. Являючи собою кібернетичну структуру, клітина диспонує різними кластерами органел - сукупностями функціонально детермінованих ультраструктур. Такі функціональні кластери клітини ми позначаємо як "профілі можливостей" [70]. Для забезпечення надійної діяльності клітини профілі можливостей $\epsilon$ переважно полікомпонентними, тобто складаються 3 кількох ультраструктур, функції яких є взаємопов’язаними і взаємодоповнюючими. У цьому аспекті ми звертаємо увагу на топографічне взаєморозташування ультраструктур у кластері, що забезпечує їх зв’язок для кращого виконання функціонального завдання.

Грунтуючися на позиціях цитофізіології, ми вважаємо, що профіль синтетичної можливості гормонопоетичної клітини представляють гранулярний цитоплазматичний ретикулум, комплекс Гольджі, вільні рибосоми, які розташовані у цитоплазмі та зв’язані рибосоми, що розміщені на субструктурах гранулярного цитоплазматичного ретикулуму, а електронна щільність цитоплазми відображає інтенсивність перебігу синтетичних процесів, 
які відбуваються в клітині; профіль секреторної можливості представляють лізосоми і секреторні гранули, а у фолікулярних тироцитах ЩЗ до цього переліку долучають мікроворсинки їх апікальних поверхонь та електронну щільність інтрафолікулярного колоїду; профіль транспортувальної можливості характеризується перикапілярним простором, ендотеліоцитами мікрокапілярного русла, базальними мембранами фолікулярних тироцитів; профіль енергетичної можливості характеризується мітохондріями [71].

Вивченню підлягають ультратонкі (4-6мкм) зрізи досліджуваної гормональної тканини, виготовлені за рутинними методиками електронномікроскопічного дослідження. Після візуального огляду для 3'ясування гістологічної картини приступають до іiі поглибленого вивчення. Інноваційним $є$ запропоноване нами поєднання традиційних i сучасних математичних методів. Зокрема, ми застосовуємо принцип фазового інтервалу [72], суть якого полягає у математичному визначенні евклідової відстані між двома точками багатовимірного простору. Тоді визначення фактичного стану ультраструктури досягається його співставленням зі станом аналогічних ультраструктур у двох діаметрально протилежних контролях, якими $\epsilon$ ці структури в нормі та при досліджуваній патології. Спираючися на принципи Fuzzy logic [73], кількість і стан кожної ультраструктури профілю досліджуваної можливості ранжують у межах "мало - помірно - багато". Після цього їм присвоюють відповідний символ і проводять цифрове оцінювання відповідно до вираженості проявів від 1 до 4 балів. Цифрові параметри оцінювання можна позначати також й у відсотках [74]. Таким чином відбувається трансформування якісної та бінарної інформації про стан клітини в кількісну інформацію, яка відповідно до вимог математичної статистики усереднюється 3 визначенням середнього арифметичного та його стандартної похибки $(\mathrm{M} \pm \mathrm{m})$. Отримані цифрові показники можна використовувати як первинний матеріал для створення баз даних або для математичних перетворень при поглибленому дослідженні. 
Інформативним i перспективним є залучення методу корелящійиного аналізу [75]. Застосувавши відому формулу Пірсона 3 подальшою інтерпретацією отриманих результатів лінійної кореляції за шкалою Чеддока [76], встановлюють силу і напрямок простежених кореляційних зв'язків. При цьому найбільш значимими вважаються прямі дуже міuні і прямі міцุні кореляційні зв'язки; при їх відсутності дослідженню підлягають прямі помітні і прямі помірні зв'язки. Водночас непрямі зв'язки часто можуть підтвердити інформацію, отриману аналізуванням прямих зв'язків, і тому також потребують вивчення. Такий підхід дає можливість глибоко дослідити вплив різноманітних чинників на різні аспекти діяльності фолікулярного тироциту. Це досягається ще однією інноваційною методикою - побудовою кореляційних портретів профілів можливостей [77], що є графічним відображенням кореляційних зв'язків, які були встановлені між складовими елементами профілю однієї можливості (внутрішньосистемний кореляційний портрет) або між елементами профілів різних можливостей (міжсистемний кореляційний портрет). Аналізування інформації, отриманої за допомогою кореляційних портретів, також проводиться на підставі інтерпретування даних цитофізіології [78,79] про функціональну роль кожної органели, яка належить до досліджуваного профіля. Узагальнену характеристику портрета як цілісної структури встановлюють його наближенням/віддаленням до норми/патології. Як приклад, наводимо кореляційні портрети секреторної можливості фолікулярних тироцитів білих щурів-самців, яким дефіцит йоду в раціоні коригували тією самою дозою органічного (Рис. 1a) та неорганічного (Рис. 1b) йоду [80].

Особливе значення репрезентований метод дослідження стану ЩЗ [81] може набути в нинішніх умовах пандемії COVID-19. За даними автопсій осіб, які померли від Covid-19, патологічні зміни в організмі характеризуються значною різноманітністю і ураженням багатьох органів [82]. Так, у легенях, які є органом-мішенню вірусу, спостерігаються дифузні альвеолярні ураження на тлі тромбозу артерій дрібного калібру, гострі альвеоліти, поєднані 3 тромбоваскулітами, інфаркти легень [83,84]. Ураження міокарда [85] 
проявляються гострим інфарктом міокарда, міокардитом, кардіоміопатіями, загибеллю кардіоміоцитів. Ще одним органом-мішенню є нирки [86], в яких уражаються функціонально значимі елементи - капсула Боумена та епітелій проксимальних канальців; описані випадки ураження капілярних петель клубочків. У 14-53\% автопсій в тканині печінки відбувається активізація процесів апоптозу. У скелетних м'язах спостерігається відсутність специфічної посмугованості рабдоміоцитів та вогнищевий некроз їх цитоплазми. Отже, основними патоморфологічними проявами коронавірусного ураження $€$ порушення кровообігу, дистрофіїя некроз, запалення. Оскільки зазначені патологічні явища першочергово супроводжуються розладами білкового обміну, зокрема, білкового синтезу, стан ЩЗ набуває особливого значення під час хвороби та є дуже важливим для повноцінної реконвалесценції. Після одужання необхідно оцінити тиреоїдну функцію для виявлення потенційного гіпотиреозу, а в пацієнтів із тяжким перебігом/гострою фазою Covid-19 рекомендується регулярне спостереження за станом ЩЗ. Водночас результати дослідження мікроскопічної структури Щ3 при COVID-19 показали наявність апоптозу фолікулярних тироцитів, їх десквамацію в колоїд та втрату фолікулами колоїду без ознак некрозу та лімфоцитарної інфільтрації [87]. Зазначені патоморфологічні зміни можуть бути ознаками безпосередньої дії вірусу на Щ3. Із цим припущенням корелюють повідомлення щодо можливості провокування перенесеним захворюванням розвитку атипового підгострого тиреоїдиту (тиреоїдит де Кервена) та хвороби Грейвса.

Вважають, що деструктивний процес у ЩЗ може бути зумовлений необоротними ураженнями тироцитів або синдром низького рівня трийодтироніну (синдром нетиреоїдної патології), який конкретно не пов'язаний з інфекцією COVID-19, але є наслідком тяжкого стану пацієнта [88]. Поточна оцінка наслідків пандемії COVID-19 дозволить виявити більше інформації про захворювання ЩЗ, спричинені коронавірусом. Водночас беручи до уваги особливості мікроелементного ландшафту України пильну увагу 
необхідно приділяти з'ясуванню наслідків дії вірусу на Щ3 і організм у цілому в йододефіцитних ареалах країни.

$a$

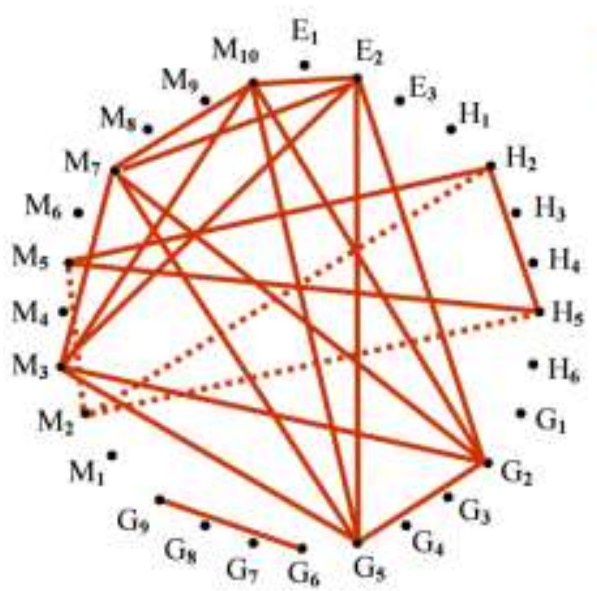

$b$

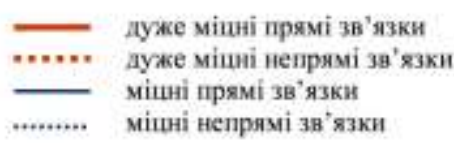

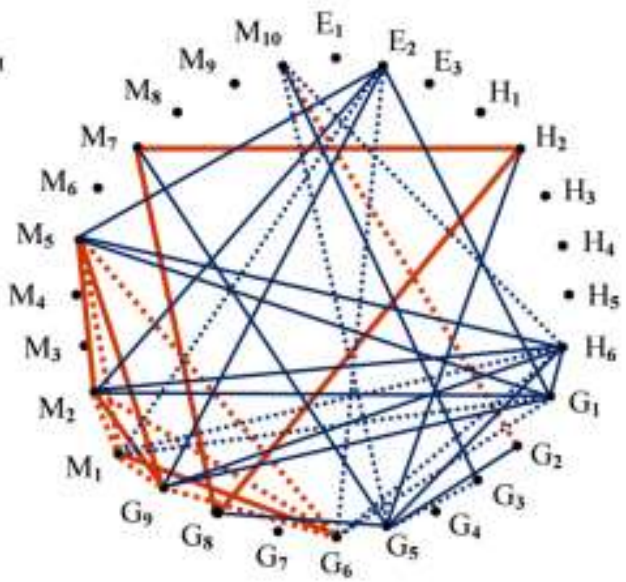

Рис. 1. Графічне зображення структури кореляційних портретів секреторного напряму діяльності фолікулярних тироцитів щитоподібних залоз білих щурів-самців, які отримували 50 мкг/кг маси тіла йоду органічної $(\boldsymbol{a})$ та неорганічної $(\boldsymbol{b})$ хімічної природи в модельних умовах дефіциту йоду в раціоні.

Таким чином, в умовах пандемії COVID-19 поглиблене вивчення особливостей діяльності ЩЗ як органу, який $є$ важливою складовою частиною систем "гіпоталамус — гіпофіз — щитоподібна залоза" [89], "щитоподібна залоза - надниркові залози" [90], "щитоподібна залоза — гонади" та бере активну участь у процесах білкового синтезу, обміну речовин і відтворення тканин, є вкрай необхідним [91].

Висновки. Мультидисциплінарні (біохімічні, патоморфологічні, гістологічні, клінічні) дослідження свідчать про важливе значення, яке щитоподібна залоза має для забезпечення життєдіяльності всіх органів і систем організму, що потребує необхідність створення міжвузівської мультидисциплінарної робочої групи з розробки та вдосконалення медичних стандартів у вигляді уніфікованих клінічних протоколів щодо медичної допомоги хворим на Covid-19, розроблених на засадах доказової медицини i доказової фармації у відповідності до МКХ-11. 
У сучасних умовах пандеміï Covid-19 та появи нових штамів коронавірусу, зокрема Omicron i Delta, дослідження щитоподібної залози 3 огляду на ii функціональну спрямованість може посісти провідну роль у пошуку нових підходів до оптимізування лікування та постковідного повноцінного відновлення пацієнтів.

Розкриття глибинної суті процесів, які відбуваються в щитоподібній залозі в нормі та патології можливе на основі інноваційного використання кореляційного аналізу 3 побудовою кореляційних портретів основних напрямків діяльності фолікулярних тироцитів.

Вивчення глибинних особливостей гормонопоезу сприяє застосуванню математичних методів, насамперед моделювання, при вивчені характеристик впливу різних чинників на морфо-функціональний стан щитоподібної залози. Це $є$ потужним сучасним пізнавальним механізмом, спрямованим як на вивчення змін у залозі як окремому органі, так і тих змін у ній, які можуть виникати у відповідь на зміни в інших органах, що сприятиме правильному підбору лікарських засобів для фармакотерапії.

Дослідження діяльності щитоподібної залози виходить за рамки однієї наукової галузі, що передбачає комплексне застосування фізіологічних, морфологічних, біохімічних, клінічних, фармацевтичних, фармакоекономічних, технологічних, юридичних та інших напрямків наукових досліджень, зокрема вивчення судово-фармацевтичних ризиків лікування та медичної реабілітації, створення міжвузівської мультидисциплінарної робочої групи 3 розробки та вдосконалення медичних стандартів (уніфікованих клінічних протоколів) медичної допомоги на засадах доказової медицини i доказової фармації.

\section{Лiтература.}

1. COVID-19, Coronavirus Pandemic: Coronavirus Statistics // Worldometer, 25.01.2022. URL: https://www.worldometers.info/coronavirus/. 
2. Оперативна інформація про поширення та профілактику COVID-19 // MO3 України, 25.01.2022. URL: https://moz.gov.ua/article/news/operativnainformacija-pro-poshirennja-koronavirusnoi-infekcii-2019-cov19.

3. Фалалєєва Т. Дослідження антитіл для оцінки стану щитоподібної залози // Медична лабораторія CSD, 07.12.2021. URL: https://www.csdlab.ua/news/doslidzhennya-antytil-dlya-otsinky-stanushchytopodibnoyi-zalozy.

4. Editorial. The untapped potential of the thyroid axis // The Lancet Diabetes and Endocrinology. 2013 Nov 01. Vol. 1, Iss. 3. P. 163 DOI: https://doi.org/10.1016/S2213-8587(13)70166-9.

5. У жінок проблеми із гормонами щитовидної залози виникають вдесятеро частіше, ніж у чоловіків // Центр громадського здоров'я МО3 України, 25.05.2020. URL: https://phc.org.ua/news/u-zhinok-problemi-iz-gormonamischitovidnoi-zalozi-vinikayut-vdesyatero-chastishe-nizh-u.

6. Устінов О.В. Здоров'я щитовидної залози: інформація для лікарів і пацієнтів // Український медичний часопис, 26.05.2020. URL: https://www.umj.com.ua/article/178989/zdorov-ya-shhitovidnoyi-zaloziinformatsiya-dlya-likariv-i-patsiyentiv.

7. Scappaticcio L., Pitoia F., Esposito K. et al. Impact of COVID-19 on the thyroid gland: an update // Reviews in Endocrine and Metabolic Disorders. 2021. Vol. 22, P. 803-815. DOI: https://doi.org/10.1007/s11154-020-09615-z.

8. Hennessey J.V. COVID-19 and how it is affecting me as a thyroidologist // Clinical Thyroidology. 2020. Vol. 32, No. 4. P. 154-155. DOI: https://doi.org/10.1089/ct.2020;32.154-155.

9. Chuiev, Y., \& Shapovalova, V. (2021). Interdisciplinary Pharmacoeconomic Study of Pharmacotherapy of Cupping of Drunk Forms of Alcohol Dependence: Clinical and Pharmacological, Organizational, Legal and Marketing Experiment. SSP Modern Pharmacy and Medicine, 1(2), 1-12. https://doi.org/10.53933/sspmpm.v1i2.24

10. Shapovalova V.A., Zbrozhek S.I., Suprun E.V., Shapovalov Valentin V., Shapovalov V.V. Coronavirus disease pandemia 2019: growth of epidemic dangers // 
Acta scientific pharmaceutical sciences. 2020. Vol. 4, Iss. 7. P. 61-68. URL: https://www.actascientific.com/ASPS/ASPS-04-0559.php.
11. Бутко
А.Ю., Шаповалов
В.В., Шаповалова
B.О., Тарасова I.В. Організаційно-правові принципи фармацевтичного забезпечення осіб, що страждають на серцево-судинні захворювання, цукровий діабет II типу, бронхіальну астму // Збірник наук. праць співробітників НМАПО ім. П.Л. Шупика. Київ, 2018. С. 46-58.

12. Шаповалова В.О., Зброжек С.І., Шаповалов В.В. Контент-аналіз аптечних закладів України, де виготовляють екстемпоральні лікарські засоби // Здоров'я суспільства. 2017. Т. 6 . № 7. С. 77-83. URL: http://nbuv.gov.ua/UJRN/zdc_2017_6_3-4_18.

13. Рябуха O.I. Деякі аспекти впливу щитоподібної залози на стан організму в умовах норми і патології // Актуальні проблеми сучасної медицини. 2018; 18, 3(63): 324-330. URL: http://nbuv.gov.ua/UJRN/apsm_2018_18_3_69.

14. Міщенко С.Г. Щитоподібна залоза - як діагностувати проблеми? // Медичний центр ON Clinic, 25.01.2022. URL: https://onclinic.ua/blog/shitovidnazaloza-yak-diagnostuvaty-problemy.

15. Чукур О.О. Динаміка захворюваності й поширеності патології щитоподібної залози серед дорослого населення України // Вісник соціальної гігієни та організації охорони здоров’я України. 2018. № 4. С. 19-25. DOI: https://doi.org/10.11603/1681-2786.2018.4.10020.

16. Kalra S., Aggarwal S., Khandelwal D. Thyroid dysfunction and dysmetabolic syndrome: The need for enhanced thyrovigilance strategies // International Journal of Endocrinology. 2021 Mar 30. Vol. 2021, Article ID 9641846. DOI: https://doi.org/10.1155/2021/9641846.

17. Lee S.A., Choi D.-W., Kwon J. et al. Association between continuity of care and type 2 diabetes development among patients with thyroid disorder // Medicine (Baltimore). 2019 Dec 27. Vol. 98, No. 52. P. e18537. DOI: https://doi.org/10.1097/MD.0000000000018537. 
18. Шаповалова В. А. Лекарственные средства в неврологи, психиатрии и наркологии / за ред. В.А. Шаповаловой, П. В. Волошина, А. В. Стефанова и др. Харьков: Факт, 2003. 784 с.

19. Ryabukha O.I. To the structural and functional preconditions of the emergence of thyroid pathology (literature review) // Achievements of Clinical and Experimental Medicine. 2018; 2: 16-24. DOI: http://doi.org/10.11603/1811-2471.2018.v0.i2.8903. 20. Murugan A.K., Alzahrani A.S. SARS-CoV-2: Emerging role in the pathogenesis of various thyroid diseases // J Inflamm Res. 2021. No 14, P. 6191-6221. DOI: https://doi.org/10.2147/JIR.S332705.

21. Chia P.Y., Ong S.W.X., Chiew C.J. et al. Virological and serological kinetics of SARS-CoV-2 Delta variant vaccine breakthrough infections: a multicentre cohort study. Clinical microbiology and infection. 2021 Nov 23. Article ID S1198743X(21)00638-8. DOI: https://doi.org/10.1016/j.cmi.2021.11.010.

22. Enhancing readiness for Omicron (B.1.1.529): Technical brief and priority actions for Member States // World Health Organization HQ. 2021 Dec 23. URL: https://cutt.ly/6IrAIoV.

23. Devlin H. Omicron found to grow 70 times faster than Delta in bronchial tissue // The Guardian, 2021 Dec $15 . \quad$ URL: https://www.theguardian.com/world/2021/dec/15/omicron-found-to-grow-70-timesfaster-than-delta-in-bronchial-tissue.

24. Staff T. Omicron variant found to grow 70 times faster than Delta in respiratory tissue // The Times of Israel, 2021 Dec 16. URL: https://www.timesofisrael.com/omicron-variant-found-to-grow-70-times-faster-thandelta-in-respiratory-tissue/.

25. Zhang, Y., Lin, F., Tu, W. et al. Thyroid dysfunction may be associated with poor outcomes in patients with COVID-19 // Molecular and cellular endocrinology. 2021. Vol. 521. Article ID 111097. DOI: https://doi.org/10.1016/j.mce.2020.111097.

26. Khoo B., Tan T., Clarke S.A. et al. Thyroid Function Before, During, and After COVID-19 // The Journal of Clinical Endocrinology \& Metabolism. 2021 Feb. Vol. 106, Iss. 2. P. e803-e811. DOI: https://doi.org/10.1210/clinem/dgaa830 
27. Чоп'як В.В., Федоров Ю.В. Особливості застосування фторхінолонів у клінічній практиці // Клиническая антибиотикотерапия: Специализир. информ. изд. 2005. № 2. С. 31-33.

28. Регеда М.С., Олекшій П.В. Особливості порушень активності глутатіонпероксидази в тканинах пародонта в динаміці розвитку іммобілізаційного стресу // Патологічна фізіологія - охороні здоров'я України : матеріали VIII національного конгресу патофізіологів (м. Одеса, 13-15 трав. 2020 р.). Одеса, 2015. C. 264-265.

29. Hayduchok I., Shapovalov V. Covid-19: Multidisciplinary Researches of Forensic and Pharmaceutical Risks and Causal Relationships of Unqualified Medical Care for Patients During Pandemic // SSP Modern Law and Practice. 2022. Vol. 2, No. 1. P. 1-25. https://ssp.ee/index.php/mlp/article/view/39

DOI: https://doi.org/10.53933/sspmlp.v2i1.39.

30. Shapovalova V., Zakharchenko I. Organizational and Legal Approaches to Reforming of the Law Enforcement System of Ukraine: Illegal Circulation of Psychoactive Substances and Addictive Dependence // SSP Modern Law and Practice. 2021. Vol. 1, No. 1 . P. 1-22. DOI: https://doi.org/10.53933/sspmlp.v1i1.20. 31. Особливості продукції IFN- $\alpha$ у хворих на рецидивуючу герпесвірусну інфекцію 1-го та 2-го типів / Н.М. Горбаль, К.Е. Іщейкін, Г.О. Потьомкіна, І.Г. Гайдучок, І.Й. Кріль, В.В. Чоп’як // Семейная медицина. 2019. № 3. С. 37-42. URL: http://nbuv.gov.ua/UJRN/simmed_2019_3_99.

32. Ryabukha O.I. Ultrastructural features of the follicular thyrocytes' synthetic activity while taking organic iodine under conditions of alimentary iodine deficiency // Bulletin of Problems in Biology and Medicine. 2017; 4, 2(140): 134-139. URL: https://vpbm.com.ua/ua/vipusk-4-tom-2-(140),-2017/9557.

33. Ryabukha O.I. Study of the follicular thyrocytes' synthetic activity while taking inorganic iodine under conditions of alimentary iodine deficiency // Bulletin of Problems in Biology and Medicine. 2017; 4, 3(141): 218-223. DOI: http://doi.org/10.29254/2077-4214-2017-4-3-141-218-223. 
34. Ryabukha O.I. Search for markers of changes of the synthetic activity of thyrocyte under the influence of iodine reception in iodine deficiency conditions // World of Medicine and Biology. 2018; 3(65): 179-185. DOI: http://doi.org/10.26724/2079-8334-2018-3-65-179-185.

35. Ryabukha O, Dronyuk I. Applying regression analysis to study the interdependence of thyroid, adrenal glands, liver, and body weight in hypothyroidism and hyperthyroidism // CEUR Workshop Proceedings-Series. 2019; 2488: 155-164. URL: http://ceur-ws.org/Vol-2488/paper13.PDF.

36. Ryabukha O., Dronyuk I. Applying of information technologies for study of the thyroid gland follicular thyrocytes' synthetic activity // CEUR Workshop Proceedings-Series. 2020; 2753: 323-337. URL: http://ceur-ws.org/Vol2753/paper23.pdf.

37. Ryabukha O., Dronyuk I. Modern approaches to the applying of mathematical methods in the analysis of the transport direction of follicular thyrocytes // CEUR Workshop Proceedings-Series. 2021; 3038: 302-316. URL: http://ceur-ws.org/Vol3038/paper19.pdf.

38. Ryabukha O.I. Study of ultrastructure profile of follicular thyrocytes' transport capabilities by means of correlation analysis // Medical Informatics and Engineering. 2021; 3-4: 28-38. DOI: https://doi.org/10.11603/mie.1996-1960.2021.3-4.12638.

39. Ryabukha O.I., Fedorenko V.I. Environmental determinants of thyroid pathology // Medicni perspectivi. 2021; 26, 3: 169-178. DOI: https://doi.org/10.26641/2307$\underline{0404.2021 .3 .242253}$

40. Зміни до «Положення про мультидисциплінарну робочу групу з розробки медичних стандартів (уніфікованих клінічних протоколів) медичної допомоги на засадах доказової медицини». Затверджено Наказом МO3 України 29.12.2016 № 1422 "Про внесення змін до наказу Міністерства охорони здоров’я України від 28 вересня 2012 року № 751". Зареєстровано в Міністерстві юстиції України 24 квітня 2017 р. за № 532/30400 // Верховна Рада України, 29.12.2016. URL: https://zakon.rada.gov.ua/laws/show/z0532-17\#n11. 
41. Shapovalova V. The ICD-11 For the Twenty-First Century: The First View from The Organizational, Legal, Clinical and Pharmacological Aspects // SSP Modern Pharmacy and Medicine, 2022 Vol. 2. - No. 1, p. 1-13 https://doi.org/10.53933/sspmpm.v2i1.37.

42. Ryabukha O.I. Body weight as an indicator of the organism's general condition while receiving iodine of organic and inorganic chemical origin under conditions of the optimal iodine supplementing // Bulletin of problems in biology and medicine. 2018; 1, 1(142): 97-102. DOI: https://doi.org/10.29254/2077-4214-2018-1-1-14297-102.

43. Ryabukha O.I. Dynamics of the body weight changes induced by iodine of organic and inorganic chemical nature in the conditions of subclinical hyperthyroidism. Acta Medica Leopoliensia. 2020; 26, 1: 62-69. DOI: https://doi.org/10.25040/aml2020.01.062.

44. Ryabukha O.I. Weight of the thyroid, adrenal glands, and the liver of white rats in the conditions of hyperthyroidism: the possibility of applying indices changes as screening-markers for determining body status effected by organic and inorganic iodine // Medicni perspectivi. 2020; 25, 2: 149-155. DOI: https://doi.org/10.26641/2307-0404.2020.2.206793.

45. Ryabukha O.I. Peculiarities of thyroidal colloid hormonal activity of white rats' thyrocytes during consumption of organic and inorganic iodine in conditions of potentiated alimentary iodine deficiency // World of Medicine and Biology. 2020; 4: 193-198. DOI: https://doi.org/10.26724/2079-8334-2020-4-74-193-198.

46. Ryabukha O.I. Hormonal activity features of intrafollicular colloid of white rat's thyroid gland in common disorders of its function // Bulletin of Problems in Biology and Medicine. 2021; 1: 245-250. DOI: https://doi.org/10.29254/2077-4214-2021-1159-244-250.

47. Ryabukha O.I. The content of ascorbic acid in the liver and adrenal glands of rats during correction of alimentary hypothyrosis by an iodine of a different chemical nature // Medical and Clinical Chemistry. 2018; 20, 1: 51-58. DOI: http://doi.org/10.11603/mcch.2410-681X.2018.v0.i1.8841. 
48. Ryabukha O.I. Iodine content in white rats thyroid glands in organic and inorganic iodine administration under the conditions of subclinical hyperthyroidism // Medical and Clinical Chemistry. 2020; 22, 1: 91-98. DOI: https://doi.org/10.11603/mcch.2410-681X.2020.v.i1.11060.

49. Рябуха О.І. Вікові особливості поглинання радіоактивного йоду (131I) щитоподібними залозами щурів при коригуванні дефіциту йоду в раціоні йодом органічної хімічної природи // The Medical and Ecological Problems. 2021; 25, 1 2: 26-30. DOI: https://doi.org/10.31718/mep.2021.25.1-2.07.

50. The Global Cancer Observatory. Thyroid. Source: Globocan 2020 // International Agency for Research on Cancer. World Health Organization. URL: https://gco.iarc.fr/today/data/factsheets/cancers/32-Thyroid-fact-sheet.pdf.

51. Drozd V.M., Branovan I., Shiglik N. et al. Thyroid cancer induction: Nitrates as independent risk factors or risk modulators after radiation exposure, with a focus on the Chernobyl accident // European Thyroid Journal. 2018. Vol. 7. P. 67-74. DOI: https://doi.org/10.1159/000485971.

52. Тронько М.Д., Пастер І.П., Стаценко О.А., Гирявенко О.Я. 30 років після аварії на Чорнобильській АЕС: огляд публікацій у журналі "Ендокринологія" // Ендокринологія. 2016. Т. 21, № 2. С. 166-176. URL: https://endokrynologia.com.ua/index.php/journal/article/view/181/155.

53. Chandra A. K. Iodine, thiocyanate and the thyroid // Biochemistry and Pharmacology (Los Angeles). 2015. Vol. 4, Iss. 3. Article 1000171. DOI: https://doi.org/10.4172/2167-0501.1000171.

54. Ендокринні руйнівники в Україні: стан проблеми та шляхи іï вирішення : нац. огляд / А. М. Сердюк, Д. А. Базика, М. Д. Тронько та ін. Київ: Медінформ, 2018. $155 \mathrm{c}$.

55. Li X., Gao Y., Wang J. et al. Exposure to environmental endocrine disruptors and human health // Journal of Public Health and Emergency. 2017. Vol. 1, No. 8. DOI: http://dx.doi.org/10.21037/jphe.2016.12.09. 
56. Fiore M., Conti G.O., Caltabiano R. et al. Role of emerging environmental risk factors in thyroid cancer: A brief review // International Journal of Environmental Research and Public Health. 2019. Vol. 16, No. 7. Article 1185. DOI: https://doi.org/10.3390/ijerph16071185.

57. Гжегоцкий М.Р., Шафран Л.М., Штабский Б.М. О системном подходе в гигиеническом нормировании ксенобиотиков // Вестник КазНМУ: електрон. версия журн. 2014. URL: https://articlekz.com/article/27379.

58. Menon K., Skeaff S. Iodine: Iodine Deficiency Disorders (IDD) / B. Caballero, P.M. Finglas, F. Toldrá (ed.) // Encyclopedia of Food and Health. New York: Academic Press; 2016. p.p. 437-443. DOI: https://doi.org/10.1016/B978-0-12384947-2.00399-8.

59. Aburto N., Abudou M., Candeias V., Wu T. Effect and safety of salt iodization to prevent iodine deficiency disorders: a systematic review with meta-analyses / WHO eLibrary of Evidence for Nutrition Actions (eLENA). Geneva: World Health Organization; 2014. URL: https://www.who.int/publications/i/item/9789241508285.

60. Santos J.A.R., Christoforou A., Trieu K. et al. Iodine fortification of foods and condiments, other than salt, for preventing iodine deficiency disorders. Cochrane Database of Systematic Reviews. 2019. Vol. 2, No 2. Article CD010734. DOI: https://doi.org/10.1002/14651858.CD010734.pub2.

61. Тронько М., Кравченко В. Значення йоду для організму, найбільш вагомі його дослідження та перспективи запровадження йодної профілактики в Україні // Ендокринологія. 2021. Т. 26, № 1. С. 59-74. DOI: https://doi.org/10.31793/1680-1466.2021.26-1.59.

62. Корзун В., Антонюк I. Солодкі соуси для профілактики йоддефіцитних захворювань // Товари і ринки. 2012. № 1. С. 89-94. URL: http://nbuv.gov.ua/UJRN/tovary_2012_1_12.

63. Корзун В. Н., Воронцова Т. О., Антонюк І. Ю. Вивчення впливу чорноморських водоростей на функцію щитоподібної залози та профілактику йододефіцитних станів / Екологія і захворювання щитоподібної залози. Київ: Медінформ, 2018. С. 607-622. 
64. Кравченко В.М., Орлова В.О., Лар'яновська Ю.Б., Сахарова Т.С. Дослідження впливу водного екстракту ламінарії на морфологічний стан щитоподібної залози щурів з експериментальним гіпотиреозом, спричиненим перхлоратом натрію // Український біофармацевтичний журнал. 2017. № 6. С. 50-55. DOI: https://doi.org/10.24959/ubphj.17.144.

65. Рябуха О. I. До питання застосування при гіпотиреозі неорганічного та органічного йоду (огляд). Актуальні проблеми транспортної медицини. 2018; 2(52): 7-21. DOI: http://doi.org/10.5281/zenodo.1319531.

66. Автандилов Г. Г. Основы количественной патологической анатомии: учебное пособие. Москва: Медицина, 2002. 240 с.

67. Автандилов Г. Г. Медицинская морфометрия: Руководство. Москва: Медицина, 1990. 384 с.

68. Ryabukha O.I. Conceptual approaches to the study of the thyroid gland at different levels of its integration into the body // Endocrinology and Disorders. 2020; 4, 1. DOI: https://doi.org/10.31579/2640-1045/047.

69. Ryabukha O. I. Substantiation of conceptual apparatus for mathematical studies on the hormone-producing cell activity // Bulletin of problems in biology and medicine. 2018; 3, 1(145): 234-237. DOI: http://doi.org/10.29254/2077-4214-20183-145-234-237.

70. Ryabukha O. I. Perspectives of applying new approaches to the implementation of mathematical technologies in the study of cell activity // Medical Informatics and Engineering. 2018; 1: 67-75. DOI: https://doi.org/10.11603/mie.19961960.2018.1.8894.

71. Ryabukha O. Innovative model for studying the features of hormono-poietic cells functioning based on characteristics of different aspects in their activity (as examplified by follicular thyrocytes) / Scientific basis of modern medicine: collective monograph. Boston: Primedia eLaunch, 2020. pp. 171-181. DOI: https://doi.org/10.46299/isg.2020.MONO.MED.I. 
72. Пособие для практических занятий по медицинской информатике: учебное пособие / Е.В. Плащевая, В.А. Смирнов, Н.В. Нигей, В.А. Лысак. Благовещенск: Амурская гос. мед. академия, 2014. С. 176.

73. Gürsel G. Healthcare, uncertainty, and fuzzy logic // Digital Medicine. 2016; 2,3: 101-112. DOI: https://doi.org/10.4103/2226-8561.194697.

74. Riabukha O. Application of new information technologies for the study of cell activity / Proceedings of the XIth International Conference on Perspective Technologies and Methods in MEMS Design (MEMSTECH); 2015 Sep 2-6; Lviv, Ukraine. New York (NY), United States: IEEE; 2015. P. 69-71. URL: http://ieeexplore.ieee.org/document/7299458.

75. Miot H. A. Correlation analysis in clinical and experimental studies // Jornal Vascular Brasileiro. 2018; 17, 4: 275-279. DOI: http://doi.org/10.1590/16775449.174118.

76. Котеров А.Н., Ушенкова Л.Н., Зубенкова Э.С. и др. Сила связи. Сообщение 2. Градации величины корреляции // Медицинская радиология и радиационная безопасность. 2019. T.64, № 6. DOI: https://doi.org/10.12737/1024-6177-2019-646-12-24.

77. Ryabukha O., Dronyuk I. The portraits creating method by correlation analysis of hormone-producing cells data // CEUR Workshop Proceedings-Series. 2018. Vol. 2255. P. 135-145. URL: http://ceur-ws.org/Vol-2255/paper13.pdf.

78. Caplan M.J. Functional organization of the cell / W. F. Boron, E. L. Boulpaep (Eds.). Medical Physiology, 3rd ed. Philadelphia: Elsevier, 2016. pp. 8-46.

79. Гжегоцький М. Р., Петришин Ю. С., Мисаковець О. Г. Фізіологія : навч.метод. посібник / за ред. М. Р. Гжегоцького. Вінниця : Нова Книга, 2019. 464 с. 80. Ryabukha O.I, Dronyuk I.M. Application of correlation analysis in cytology: Opportunities to study specific activity of follicular thyrocytes // Regulatory Mechanisms in Biosystems. 2019; 10, 3: 345-351. DOI: https://doi.org/10.15421/021953.

81. Ryabukha O.I. Application of mathematical approaches in medicine on the example of follicular thyrocytes secretory activity study // World of Medicine and 
Biology. 2019; 1(67): 181-187. DOI: https://doi.org/10.26724/2079-8334-2019-1-67181.

82. Коган Е.А., Березовский Ю.С., Проценко Д.Д. и др. Патологическая анатомия инфекции, вызванной SARS-COV-2 // Судебная медицина. 2020. T. 6, Вып. 2. C. 8-30. DOI: https://doi.org/10.19048/2411-8729-2020-6-2-8-30.

83. Aguiar D., Lobrinus J. A., Schibler M. et al. Inside the lungs of COVID-19 disease // International Journal of Legal Medicine. 2020. Vol. 134. No. 4. P. 12711274. DOI: https://doi.org/10.1007/s00414-020-02318-9.

84. Pomara C., Volti G. L., Cappello F. COVID-19 Deaths: Are We Sure It Is Pneumonia? Please, Autopsy, Autopsy, Autopsy! // Journal of Clinical Medicine. 2020. Vol. 9. No. 5. P. 1259. DOI: https://doi.org/10.3390/jcm9051259.

85. Bansal M. Cardiovascular disease and COVID-19. Cardiovascular disease and COVID-19 // Diabetes and Metabolic Syndrome. 2020. Vol. 14. No. 3. P. 247-250. DOI: https://doi.org/10.1016/j.dsx.2020.03.013.

86. Su H., Yang M., Wan C., Yi L et al. Renal histopathological analysis of 26 postmortem findings of patients with COVID-19 in China // Kidney International. 2020. Vol. 98. No. 1. P. 219-227. DOI: https://doi.org/10.1016/j.kint.2020.04.003.

87. Feghali K., Atallah J., Norman C. Manifestations of thyroid disease post COVID-19 illness: Report of Hashimoto thyroiditis, Graves' disease, and subacute thyroiditis // Journal of Clinical Translation Endocrinology: Case Reports. 2021. Vol. 22. Article 100094. DOI: https://doi.org/10.1016/j.jecr.2021.100094.

88. Baldelli R., Nicastri E., Petrosillo N. et al. Thyroid dysfunction in COVID-19 patients // Journal of Endocrinological Investigation. 2021 Dec; 44(12): 2735-2739. DOI: https://doi.org/10.1007/s40618-021-01599-0.

89. Ortiga-Carvalho T.M., Chiamolera M.I., Pazos-Moura C.C., Wondisford F.E. Hypothalamus-pituitary-thyroid axis // Comprehensive Physiology. 2016. Vol. 6, No. 3. P. 1387-1428. DOI: https://doi.org/10.1002/cphy.c150027.

90. Ryabukha O., Greguš ml M. Correlation analysis as a thyroid gland, adrenal glands, and liver relationship tool for correcting hypothyroidism with organic and 
inorganic iodine // Procedia Computer Science. 2019; 160: 598-603. DOI: https://doi.org/10.1016/j.procs.2019.11.041.

91. Ryabukha O. COVID-19 Pandemic Encourages to Deepen the Study of the Thyroid Gland: Correlation Portraits as a Means of Research in Different Directions of Follicular Thyrocytes Activities // SSP Modern Pharmacy and Medicine. 2022; 2(1): 1-21. https://ssp.ee/index.php/mpm/article/view/40

DOI: https://doi.org/10.53933/sspmpm.v2i1.40. 